\title{
God is not a person (an argument via pantheism)
}

\section{Simon Hewitt ${ }^{1}$ D}

Received: 22 November 2017 / Accepted: 3 July 2018 / Published online: 6 July 2018

(c) The Author(s) 2018

\begin{abstract}
This paper transforms a development of an argument against pantheism into an objection to the usual account of God within contemporary analytic philosophy ('Swinburnian theism'). A standard criticism of pantheism has it that pantheists cannot offer a satisfactory account of God as personal. My paper will develop this criticism along two lines: first, that personhood requires contentful mental states, which in turn necessitate the membership of a linguistic community, and second that personhood requires limitation within a wider context constitutive of the 'setting' of the agent's life. Pantheism can, I argue, satisfy neither criterion of personhood. At this point the tables are turned on the Swinburnian theist. If the pantheist cannot defend herself against the personhood-based attacks, neither can the Swinburnian, and for instructively parallel reasons: for neither doctrine is God in the material world; in the pantheist case God is identical with the world, in the Swinburnian case God transcends it. Either way both the pantheist and the Swinburnian are left with a dilemma: abandon divine personhood or modify the doctrine of God so as to block the move to personhood.
\end{abstract}

Keywords Pantheism · Divine personhood · Apophaticism · Divine language

Is God a person? Since the advent of philosophy of religion in the analytic tradition the consensus of opinion has favoured answering this question in the affirmative (as we will see in due course). I think that this response is wrong; God is not

Simon Hewitt

s.hewitt@leeds.ac.uk

1 School of Philosophy, Religion, and the History of Science, University of Leeds,

Leeds LS2 9JT, UK 
a person. The purpose of this paper is to trace a new route to this ancient conclusion $^{1}$. Harnessing a revival of interest in alternative concepts of deity (Buckareff and Nagasawa 2016), in what follows I flesh out and defend the personhood argument against pantheism. ${ }^{2}$ This allows us to get a relatively uncontroversial handle on the kind of reasons which might be thought to count against God being a person, in the context of a pantheistic concept of God. The innovation of the present paper consists in making a transition from the context of pantheism to that of standard analytic theism, and arguing that exactly the same reasons which count against personhood in the pantheistic case undermine personhood here too. The result is a cumulative case against divine personhood.

The personhood argument for pantheism proceeds on the basis of the claimed incompatibility of two claims which it will be useful to set out for future reference:

(1) God is everything.

(2) God is a person.

I think that it indeed cannot be the case that (1) and (2) are both true. However, I want to argue that this should not be a source of comfort for the mainstream of analytic theism (which I will call 'Swinburnian theism'). The Swinburnian theist affirms (2) whilst denying (1). This, I will argue is an untenable position, since arguments showing that (1) is incompatible with (2) also show that key Swinburnian claims are incompatible with (2). Both sides therefore face a choice: revise the operative understanding of God, or reject divine personhood. An engagement with pantheism, then, provides a novel vantage point from which to assess a standard position in philosophical theism.

I'll proceed as follows. 11 lays out the conceptual terrain, offering a working definition of pantheism and discussing reasons for assent to divine personhood. $\$ 2$ describes the personhood challenge to pantheism in broad terms, whilst $\$ 3$ enquiries into what it means to classify some entity as a person. Then in the following two sections the personhood challenge is developed along two lines: $\S 4$ argues that personhood requires potential membership of a linguistic community, which God-as understood according to (1)—cannot possess; $\$ 5$ suggests that personhood necessitates having a life context, which again the God of (1) cannot have. I go on in $\S 6$ to make the case that the arguments of $\S 4$ and $\$ 5$ tell equally against Swinburnian theism. A conclusion draws morals for the philosophy of religion, identifying some choice points and suggesting future directions of enquiry.

\footnotetext{
${ }^{1}$ It's actually cheating somewhat to call the position ancient, since the modern concept of personhood in terms of which it is formulated was not available to ancient and medieval thinkers. I hope that readers will allow me the counterfactual: the other commitments of pseudo-Dionysius, Maimodies, Aquinas and so on show us that had they possession of the relevant concept of personhood they would have denied that God is a person.

${ }^{2}$ Pantheism is touched on, both historically and with respect to contemporary perfect being theism in Nagasawa (2017, Ch. 1).
} 


\section{Pantheism and personhood}

The term 'pantheism' is somewhat vague in its application. Mander's Stanford Encyclopedia entry tells us that it 'should not be thought of as a single codifiable position' (Mander 2016). In order to engage rigorously with the topic, however, it is helpful to have a unitary working definition. The obvious one is,

(3) Everything is God.

However, the devil is in the detail. The reading of this as $\forall x x=g$, where ' $\mathrm{g}$ ' names God, is clearly not the intended one. As a poetic utterance 'we are all gods' might have something going for it, ${ }^{3}$ but it dubious that it has merits as a claim about reality. ${ }^{4}$ The pantheist instead intends something like:

(4) God is identical with the maximal mereological sum

Indeed Oppy takes (4) to be definitional of pantheism (Oppy 1997). It would be peculiar if this were exactly right: is the pantheist really committed in virtue of her pantheism to there being a maximal mereological sum? That such a sum exists is a consequence of mereological universalism, at least in the presence of absolutely general quantification, and the pantheist certainly needn't sign up to that; but need she even admit the existence of a world-sum? ${ }^{5}$ If we can make sense of the idea of non-mereological composition-invoked, for instance, by Armstrong in his account of states-of-affairs (Armstrong 1997) - then perhaps the pantheist could hold coherently that every non-divine entity composes God in a non-mereological fashion. This said we will set these considerations to one side in what follows and work with (4) as definitive of pantheism. Whilst discussions of how best to formulate pantheism are interesting, and of some importance for philosophical engagement with the doctrine, I do not think that anything which follows here turns on the precise details of formulation.

It is a corollary of (4) that everything is a part of God and that everything other than God is a proper part of God. This, I think, captures what is intended by pantheistic claims to the effect that everything is divine. Every entity is overlapped by God; there is, so to speak, nothing which lies beyond God's mereological remit.

So much for pantheism. Now to address the second side of the dilemma we'll be setting up: what reasons are there to suppose that God is a person? It could be taken to be simply analytic of the concept God that God is a person. After all, the word 'God' functions like a personal proper name, typically taking personal pronouns as anaphoric co-referrers. That personhood is definitional of God is a commonplace assumption in philosophy. Swinburne tells us that God is,

\footnotetext{
3 Thus Kate Tempest:

The gods are in the betting shops

the gods are in the caff

the gods are smoking fags out the back. (Tempest 2013, 3)

${ }^{4}$ The nearest position might be what Oppy terms 'distributive pantheism'- that every entity is divine (Oppy 1997, 325).

${ }^{5}$ Mereological universalism being the position that for any plurality $x x$ there is a fusion of the $x x$.
} 
a person without a body (i.e. a spirit), present everywhere, the creator and sustainer of the universe, a free agent, able to do everything (i.e. omnipotent), knowing all things, perfectly good, a source of moral obligation, immutable, eternal, a necessary being, holy, and worthy of worship. (Swinburne 2016, 2)

Nor is this position confined to those who think that God exists. Mackie accepts Swinburne's definition of God and goes on to argue that theism is unwarranted (Mackie 1982, 1-2).

More substantially, numerous religious texts present God as exhibiting characteristically personal qualities. The foundational texts of all of the monotheistic religions contain accounts of God speaking, undergoing emotions, performing actions, listening to prayer and so on. Moreover standard beliefs about God, whether derived from religious texts or not, seem to imply personhood: think here of the belief that God is omniscient, and therefore a knower, or that God is omnibenevolent, and therefore good. In this vein, Plantinga, arguing against the doctrine of divine simplicity, which he takes (in my view wrongly), to entail that God is a property, writes,

This view is subject to a difficulty both obvious and overwhelming. No property could have created the world; no property could be omniscient, or, indeed, know anything at all. If God is a property, then he isn't a person but a mere abstract object; he has no knowledge, awareness, power, love or life. (Plantinga 1980, 47)

The thought here is that characteristic, and religiously important, states attributed to God necessitate divine personhood. Therefore-given, presumably, that we have justifying reason to believe that these states obtain - we should believe that God is a person. For present purposes, it is worth noting that the attribution of apparently personal states to God is not confined to thinkers who deny pantheism; Spinoza has it that God is an 'infinite intellect'.

Human actions in respect of God provide another reason for taking God to be a person. In particular the practice of prayer might be thought to be intelligible only against the background of belief in divine personhood. For is not prayer a form of communication with God? In praying, believers ask things of God, in the hope that God will act; they worship God; bare their souls to God, and aspire to grow closer to God. These might appear to be paradigmatically person-directed activities. It is intelligible that I do all of these things with respect to my head of department (even if it might be doubted that, for all her admirable qualities, she quite warrants worship). If I appeared to be doing them with respect to my toaster, you would not know what to make of me. Only a person, on this view, can be the object of religious devotion; God is the object of religious devotion, therefore God is a person.

Happily, given what is to follow, I do not think that any of these considerations in favour of divine personhood are decisive. They do, however, represent a common current of opinion both inside and outside the academy. The claim that God is a person is a force to be reckoned with in the philosophy of religion, and in particular it seems to present a difficulty for pantheism as we will now see. 


\section{The personhood challenge}

Here is the personhood challenge in microcosm: the maximal mereological sum is not the right kind of thing to be a person. As a succinct statement of, what I take to be, widespread intuition this is no substitute for an argument. ${ }^{6}$ We need to flesh out the bare bones in order to have something deserving of being called a challenge to pantheism.

As a first move in this direction we might consider what is behind the thought that God is not the right kind of thing to be a person. Our concept of personhood is acquired in association with application to human beings, indeed the word 'person' seems to function as a synonym for 'human being' in many circumstances: 'who was that person I saw on the train last Thursday?' Whilst no attempt to supply necessary and sufficient conditions for personhood has commanded anything like universal assent, many efforts in this direction have considered distinctively animal, if not human, characteristics to be necessary for personhood. ${ }^{7}$ Most obviously, animalist accounts have this feature, but so do ones in the Lockean tradition: if sameness of person entails sameness of mental states over time, then inter alia persons are temporally located and have mental states. Possession of mental states, and engagement in intellectual activity more generally, are phenomena we get a handle on through attention to ourselves and other animals. It is far from clear what it would be to speak of these things outside of the context of animal life, or something like it (what we might call ordered systems susceptible to reasons). What could it be to perceive, or remember, or learn apart from the possession of animal life? Do we genuinely have a grasp of the concepts of belief or knowledge apart from their coming about through one of these prior states? If we accept (as I think we ought to) that emotions are contentful and an integral component of the reason-governed lives of persons, ${ }^{8}$ then these provide a clear case of important mental states non-accidentally related to animal embodiment.

Here, then, is an expanded form of the personhood challenge: 'human beings are the kind of things eligible for personhood because they are bodies inhabiting a world, susceptible to reasons that both flow from and guide their interactions with the world and with one another. It is because they fall within a certain subclass of the category of animals that human beings are thus eligible. Whilst we might imagine there being entities that are not animals which are nonetheless persons, these will be relevantly similar to animal persons. The maximal mereological sum is not such an entity'.

The dominant strand in the philosophy of religion dissents. Mackie begins his Miracle of Theism by agreeing with Swinburne about the personal and yet

\footnotetext{
6 Which is not to say that intuitions don't count for a lot. Kripke once remarked, 'I really don't know, in a way, what more conclusive evidence one can have about anything' (Kripke 1981, 42).

7 My own view is that the project of supplying necessary and sufficient conditions here, as opposed to merely necessary ones, is misdirected. I suspect there is a certain open-endedness built into the concept of personhood: what would we say if we met a Martian; is this a person? Recognising this, however, is a long way from saying that anything goes, as we shall see.

8 See, for instance, Nussbaum (2001).
} 
disembodied nature of their shared subject matter (Mackie will go on to deny that this subject matter exists, but for present purposes that is a minor detail ${ }^{9}$ ):

We know, from our acquaintance with ourselves and other human beings, what a person is - a person, as Swinburne explains in the ordinary modern sense. Although all the persons we are acquainted with have bodies there is no great difficulty in conceiving what it would be for there to be a person without a body: for example, one can imagine oneself surviving without a body, and while at present one can act and produce results only by using one's limbs or one's speech organs, one can imagine having one's intentions fulfilled directly, without such physical means. (Mackie 1982, 1-2)

By a series of thought experiments, then, we can imagine what it is to be a disembodied person, and so being animal-like can be no part of our concept of personhood. But we ought not to concede that we can imagine any such thing. We might very well imagine something which we take to be a case of being a disembodied person, just as we might imagine a situation which we would describe as being one in which Hesperus is not Phosphorus. In neither case, however, need we accept the description as veridical. Think about what it is like to imagine surviving without a body: you imagine 'going on' somehow after your death. Perhaps you imagine not seeing, or feeling your body: but do you still imagine seeing things? Are you situated (on earth or in 'heaven')? Is there thought happening? If so where? Do you locate it in your head, or rather where your head would be if you had a body? Our imagining of ourselves is intrinsically somatic and cannot be invoked to strip animality away from our concept of personhood.

What about 'having one's intentions fulfilled directly, without ... physical means?' Can one in fact imagine this? Suppose that I imagine intending that the pen in front of me levitate and that it does indeed levitate. What should we make of this? Note that the supposed scenario is not one in which I make the pen move by magic, say by performing some ritual, or even by repeating an incantation in my internal monologue. Nor yet is it simply one in which I desire that the pen move and in which the pen proceeds to move; for sure if I intend that $\phi$ it must be the case that I desire that $\phi$ to some extent, albeit that my desire might be regretful or otherwise non-absolute. Still there is much that any given person will desire without intending. Her desire might be that some distinct agent bring about a state of affairs through that agent's own intentional and individual action, in which case it is not the case that the bringing about of the state of affairs falls within the original agent's intention. Alternatively an agent might have contradictory desires, or desires that she recognises as for something wrong: in neither case will desire coincide with intention. ${ }^{10}$ How then are

\footnotetext{
9 See here Turner (2002).

10 Objection: but God will not have contradictory desires or desires for wrong things. Reply: No doubt, but this is to misunderstand the dialectic here. Swinburne and Mackie think that we can by an act of imagination conceive of a disembodied person such as God is supposed to be. In particular, we are supposed to be able to imagine disembodied intention on the basis of our own experience of intention; but then it is tying down intention in creatures such as ourselves that is of immediate concern.
} 
we to distinguish intention from mere desire? The lesson of Anscombe's Intention is that intentional action is conceptually prior to intention (Anscombe 1957), and it is precisely a clear case of action that is lacking in the pen case. My body does not move with respect to the pen in a fashion that could be interpreted as an action, and to suggest that the movement of the pen is itself an action of mine is to beg the question. It is, we should conclude, through the intelligible movement of bodies that intentional action is to be delineated.

It might seem as though the pantheist is in a better position than Mackie and Swinburne here, since it is not obvious that her view is of God as disembodied (perhaps a pantheistic deity has a maximal body.) But remember why the standard claim about God's disembodiment was raised above: because if God is a person then, it seems, God is an animal (or something like an animal), but a disembodied God cannot be appropriately animal like. For all the difference between the pantheist and the Swinburnian it is far from clear that pantheism can deliver that God is appropriately animal-like for personhood, or indeed that she has a body in the relevant sense. ${ }^{11}$ The objections to the conceivability of Swinburne-Mackie style disembodied personhood are based in the centrality of animality to the intelligibility of key personal concepts: self-awareness and intentional action. But animality looks to be central in each of these cases because of the limitedness that comes with animality. An animal is part of the material world, but not all of it: hence she can recognise herself by distinguishing her body from what is not her body and act upon what is not her body by means of her intentional bodily movements. Animals are non-maximal material beings; the sum of everything might very well be material-supposing materialism to be true-it is certainly not non-maximal. There is nothing that it could recognise as distinct from itself (in a sense of 'distinct' embracing not only the failure of numerical identity, but also lack of mereological inclusion), and no wider reality within which it could act.

In the next two sections, I will flesh out two particular cases of the worry that the maximality of God as conceived by pantheism disqualifies God from personhood: first that the possession of contentful states, itself having membership of a linguistic community as a prerequisite, is barred by God's maximality, second that this maximality deprives God of a life context.

\section{Language and content}

If one is a person then one, at least potentially, ${ }^{12}$ stands in contentful states. Examples of such states are asserting that $P$, believing that $P$, entertaining that $P$, denying that $P$ and so on. I do not distinguish here between what would usually be termed mental states and the state of performing a speech act, since I want to allow the

\footnotetext{
11 Where 'body' is used not simply, as in physics, to designate some unit of matter but rather something like matter as organised to constitute a life. A corpse, for example, is a body in the former, but not in the latter, sense.

12 The proviso is intended to capture, for example, pre-linguistic infants.
} 
maximum amount of generality and do not want to foreclose prematurely on who or what counts as a person. We can now ask: what is required for the possession of contentful states? Here the philosophical literature divides into mind-first, languagefirst and no priority views. ${ }^{13}$ On a mind-first view it is a pre-requisite for an agent's possessing any contentful state that she possess some mental state. On a languagefirst view it is a pre-requisite for an agent's possessing any contentful state that she have some grasp of a language. No priority views hold that in order for an agent to possess any contentful state she must both possess some mental state and have a grasp of a language. The contention of the present section is that God, as conceived of by pantheism, cannot have a grasp of a language and so cannot, on either a language first or a no priority view, be the subject of contentful states (and so, cannot be a person). This in itself is an unfortunate result for the pantheist, since it makes her hostage to the correctness of a mind-first account of content. Before moving on the main business of this section, however, I will note reasons for rejecting a mindfirst view of content. If these are cogent then, in the light of what follows, a pantheistic deity cannot be a person.

It is a familiar thought from the work of Kripke, Putnam and Burge that contents are not simply determined by the mental states of agents. That I mean dihydrogen oxide by 'water' is determined by the world and the linguistic community, and that I mean a disease of joints by 'arthritis' is determined socially. Recent work has drawn attention to the linguistic mediation of externalist content and developed an argument that this undermines mind-first accounts of content. ${ }^{14}$ If what my mental states mean is dependent, in a crucial class of cases, on the prior meaning of linguistic expressions then it cannot, on pain of vicious circularity, be that each of my linguistic expressions has its meaning determined by the prior meaning of a mental state.

Suppose then that mind-first views of content are incorrect. Then if an agent is to stand in a contentful state, she must grasp some language. I'll leave what grasping a language consists in deliberately unspecified here (what are the minimal requirements? Competence with how many expressions, say, suffices for one to count as a user of a language?). ${ }^{15}$ It is not the case that anything goes, though. In particular it is a constraint on linguistic competency that a language-user be a member of a linguistic community. Why?

What would it be to be to have a grasp of some language $\mathcal{L}$ without being a member of a community of $\mathcal{L}$-users? We can imagine an entity making noises indistinguishable from phonemes from $\mathcal{L}$, but this no more counts as speaking $\mathcal{L}$ than the accidental arrangement of dust on a distant planet into a shape indiscernible from an English sentence counts as writing. To speak $\mathcal{L}$ is, in the first instance, to use it to communicate. Of course derivatively a speaker may talk to herself, it might be claimed that a person could have acquired a language in the Pickwickian sense that they possessed it from the first moment of their existence. Second, an alternative suggestion runs, they could acquire it privately. Consider the first case, what could

\footnotetext{
13 For a helpful overview see Thornton (1998, Ch 1).

14 I have in mind especially unpublished work by Gail Leckie.

15 I happen not to think that there are neat answers to these questions, but that is for another day.
} 
possibly constitute the activity in which they are engaged when they exercise their knowledge-how ${ }^{16}$ as speaking a language in the absence of recognition by others? It is no good to note that their activity is governed by what, from the outside of the imagination, look like rules; how could it be established that they are in fact rules, as opposed to accidental or natural regularities in the absence of a legislative social context? We can hardly say at this point, 'the person could have decided upon the rules herself'. We can imagine such a decision being proclaimed by a speaker, either aloud or in her internal monologue, but it is important to see that these forms of speaking (or 'speaking' - the scare-quotes being non-optional-in the case of one's internal monologue) are derivative. For in the absence of attestation in terms of the rules of a language, no speaker can be appraised of the content of an utterance, the inferential commitments it carries with it, or indeed even whether a sound is a genuine utterance. Once a speaker knows how to follow the rules of a language, she can-as it were - play the game by herself, much as somebody might work through some chess moves alone in the privacy of her flat, but knowing how to play the game must come first. And the acquisition of knowledge how to speak a language is, of necessity, something that takes place in a community.

Suppose this were not so. There are two scenarios to consider. The first is that an entity self-legislate, enacting her own linguistic rules, which she then proceeds to follow. ${ }^{17}$ In the absence of prior linguistic resources it is wholly unclear what deciding upon rules could be: it certainly cannot be the case, for example that a non-linguistic agent says to herself, out loud or in her internal monologue, 'I shall say "Red" whenever I am confronted by a particular stimulus' since by hypothesis she lacks the resources to do this. It may be objected that she could get into the habit of making the noise "Red" whenever there is a red thing in her visual field. But what would make this noise part of a language rather than a simple physiological response, comparable to her clearing her throat in response to a tickle? What could make the difference here is the use of the noise to communicate, to give reasons to other persons. But by the nature of the case this is excluded.

Alternatively we might suppose that an entity could come into being already equipped with linguistic capacities. ${ }^{18}$ Surely this is at least possible, which suffices to defeat the worry that a pantheistic deity cannot be a person, because it cannot be a language user. Possibility claims, as we saw above when discussing immediately realised intentions, are treacherous. Suppose an entity appears, or is present from the first moment of time, and either makes noises or produces shapes such that we are tempted to describe it as a language user. What, however, could constitute its being a language user? By hypothesis the noises or shapes are not being used to communicate with other persons, so on the face of it we are in exactly the same position as that discussed in the previous paragraph. The only difference could consist in a

\footnotetext{
${ }^{16}$ We might ask, 'knowledge-how to do what? What, in particular, distinguishes this from a nervous tick, or at least a voluntary making of mere noise?

17 c.f. here Anscombe on the equivalent in morality (Anscombe 1958).

18 In the sense of fully realised linguistic capacities, rather than, say, the predispositions towards language described by a theorist such as Chomsky.
} 
brute fact that the ex nihilo practices of the entity are linguistic. Acceptance of such a brute fact amounts to an admission of defeat. It invokes a frankly magical understanding of language, entirely abstracted from the practice of communication, and this cannot be accepted.

It might be that an entity either start making noises or comes into being making them, and subsequently encounters a community of language users, its noises being somehow interpretable by them. Over time it may be incorporated into the community and be appropriately described as communicating with them. It does not follow from this that the entities were language users prior to incorporation into the community. A plausible diagnosis of our undoubted tendency to think otherwise is that we tend to identify word tokens with sounds made by speakers, forgetting that sounds only constitute words in relevant communicative contexts. ${ }^{19}$

Possession of content, then, requires membership of a linguistic community. And no pantheistic deity could be a member of a linguistic community. For who would the other members of the community be? Certainly nobody wholly distinct from the deity, since by pantheistic hypothesis there are no such persons. Could it be then that God communicates linguistically with God's proper parts? In order to assess this, we ought to be clear what is at issue. I might talk at one of my proper parts-'oh silly foot, why are you hurting after only a few miles walking?'-but I am not communicating with it, it does not reply to me, providing me with reasons for its feebleness with which I can then take issue. It is communication with a proper part, rather than simply talking at a proper part, which is required of God in order for divine possession of content to be compatible with pantheism.

What would it be for a person to communicate with one of her proper parts? She speaks (or writes, or sends a text message...) and it speaks back, in ways that are not determined by her, and from which she can learn. What is being proposed here is something altogether more exacting that the familiar phenomenon of being taken aback by an aspect of oneself, or of challenging a thought in one's internal monologue: these are indicators of the psychological complexity of persons such as ourselves. It remains the case that there is a single linguistic agent involved here. I might argue with myself in my internal monologue, but it is myself I am arguing with. ${ }^{20}$ To the extent that aspects of myself can surprise me it is precisely because they are that, aspects of myself - here, of course, the pantheist can claim a parallel, non divine persons are parts or aspects of God-but my surprise is not second-personal. In particular, when I engage with a surprising aspect of myself, a thought 'out of nowhere', the realisation of an emotion that disturbs me, I do not do so as with a conversation partner, meeting the reasons I introduce to the conversation with her own, distinct and perhaps contrary to my own. ${ }^{21}$

In conceiving of a divine person communicating with one or more of her proper parts, if indeed we can conceive of this, we are conceiving then of something remote from our own experience. The envisaged scenario is one in which a proper part of

\footnotetext{
${ }^{19}$ In other words, words-like states, money or genders are social entities.

20 The dialogal approach in contemporary philosophy of logic has as its starting point the primacy of interpersonal argument (Novaes 2016).

21 On the idea as conversation as the giving and receiving of reasons, see Brandom (1994).
} 
a person has reasons distinct from those possessed by the person in question and which may be articulated over and against that person. One parallel which might be drawn here is with social groups or organisations. The Labour Party possesses reasons (it has a reason to campaign hard for the local elections), but its constituent members also have their own reasons, which may be disjoint from or even compatible with the Party's (I have a reason to go on holiday before I go down with stress, and so I have a reason not to campaign hard for the local elections.) This certainly is an important feature of social groups, but there are many reasons that social groups have been considered not to be mereological fusions: treating them as such delivers the wrong results semantically, gives rise to difficulties about modal profile, and sits uncomfortably with our understanding of the concept of parthood, to sample a few of these reasons (Uzquiano 2004).

In fact here is good reason to doubt that anything could be constitutive of a part's having reasons distinct from the whole of which it is as a part. Suppose that $x$ is a person and $y$ a part of $x$. $y$ has a reason to $\phi$. Can it be the case that $x$ does not have a reason to $\phi$ ? It is surely flatly incoherent given the admission that $x$ has a part with a reason to $\phi$ to say this. Rather what we should say is that $x$ has a reason to $\phi$ in virtue of $y$, or in virtue of being $y$-ed, which may very well not be decisive, or be overwhelmed by countervailing reasons, but that it has a reason nonetheless. What, after all, could constitute $y$ 's reason being distinct from any reason possessed by $X$ ? In the normal course of things we can recognise distinctness of reasons amongst dialogue partners through their having disjoint animal lives. That basis for distinction is absent here, and so unless there is another basis for distinction, we should not admit the possibility that the part's reasons are not reasons for the whole.

To be a person God must have mental content; to have mental content God must be a language user; to be a language user God must belong to a linguistic community. As conceived of by pantheism God cannot belong to a linguistic community. So if pantheism is true God is not a person.

\section{Personhood and personality}

Here is another case to the same effect. Being a person involves having a life; having a life involves having a life context. No pantheistic deity can have a life context, so no such deity can be a person. In the rest of this section I'll cash out this case more slowly.

Personhood is, we might think, closely related to personality. In order to identify personal agency, and thereby interact with the persons behind it, we focus on the distinctive projects and concerns of the agent in question. The persons we encounter are some things, but not others, interested in some aspects of the world, but not others. Peter is six foot tall, a nurse, cheerful, and likely to be seen at a disco on Friday nights; he is not a five-foot, sullen lion tamer. This limitedness, the fact that personal existence is non-maximal, appears integral to our concept of personhood. We know how to identify a person and deploy the concept appropriately because their properties and actions stand out against a broader backdrop of properties they do not possess and actions they do not perform. We might call this aspect of personhood, 
which is part of what was described above as being appropriately animal-like, possession of a life. ${ }^{22}$

The attribution of life has several distinct senses. There is a biological one (dogs have lives, rocks do not, viruses are a borderline case). That is not quite what is at issue here, which is something more like the capacity to contribute to a (true) narrative in which one is a character (for which, in many cases at least, biological life is a necessary but not sufficient condition). Similarly there is an undoubted theological usage which attributes life to God ('the living God'). The mere fact of this usage doesn't, of course, establish that God has a life in the sense in which we are interested, which I take to be necessary for personhood. After all, for all that has been said so far, the theologies that make this attribution might be incoherent, claiming something of God with which other claims they make is inconsistent. As it happens, however, there is good precedent for taking God to have a life without claiming that God has a life in the present sense. Aquinas, in STh 1a, Q18, a. 3, working on an understanding of a living entity as one that is self-moving, argues that God is supremely alive since he is not moved by anything else. ${ }^{23}$ Again, this is not the sense in which I am interested in God having a life.

A life, in this sense, requires a life-context, a backdrop to the organism's engagement with the world, the stage on which the life is lived. ${ }^{24}$ I now want to suggest a reason why this stage must be numerically different from the organism itself.

First, it looks to be important that any given organism does not exhaust reality, since it is parts of reality disjoint from the organism that permit us to understand the organism's movements and utterances, the capacity for being thus understood being essential to these being actions. That he is running after the bus, or that she is shouting at the dog are constitutive of those actions being what they are. Indeed any act of running requires something on which to run, and any act of shouting involves making noise that travels beyond oneself, the air molecules one causes to vibrate being distinct from oneself. A kind of comprehensible intentional action necessary for personhood, then, might be thought to depend on the existence of something ontologically disjoint from the putative person in question.

But, the reply can be anticipated, doesn't this supposition of a necessary connection between personhood and the existence of disjoint entities rely on restricting our diet of examples? What about actions performed on oneself-the scratching of one's arm, the raising of one's eyebrow? Here the (immediate) difference made by the action concerns a part of reality which is not disjoint from the agent, yet the action

\footnotetext{
${ }^{22}$ On the relationship, in particular, between animality and freedom, see Steward (2012).

${ }^{23}$ Might a similar move be made with respect to the language of personhood? Might it be claimed that God is (truly, non-metaphorically) a person, it is just that she is a person in a different sense from that in which you and I are persons? This move is actually subtlely different from the thomistic one referenced in the many body of the text, since Aquinas is claiming that God is alive in a sense in which you and I are also alive, albeit to a higher degree. What is at issue in the personhood debate is, however, whether God is a person in the same sense in which you and I are persons. Thanks to a referee for raising this question.

${ }^{24}$ As I use it here 'organism' is simply an expression applying to any entity possessing a life. I do not imply that all such entities are, for instance, carbon-based life forms.
} 
is no less an action for this being the case. If we're tempted by this line of thought it is likely that we are imagining these actions being performed by persons such as ourselves in the context of a world that extends beyond our bodies. Here there can be no objection; we intentionally, as persons, perform actions upon our own bodies. The salient question is, however, whether movements of a body could be intelligible as actions in a context where no actions can be performed upon anything disjoint from the agent (because the agent exhausts reality). This, in my view, ought to be doubted.

It is, it seems to me, by comparison with actions performed upon the external world that actions performed upon an agent's own body are constituted as such. It is in virtue of their resemblance to externally efficacious actions that movements of a body upon itself can be recognised as cases of a person acting, rather than of random or involuntary movement. The wider reality beyond the body provides the context in which movements may be interpreted meaningfully as part of a life. The agent, like the actor, requires a stage. Yet isn't there a comeback available to the pantheist here? The existence of a wider reality may be epistemically necessary, in order that an agent's actions may be identified as such, but it need not follow that this reality is a metaphysical condition for action; there could, the claim goes, be genuine actions which could not be identified. That this is a genuine possibility entails a thoroughgoing realism about action, there are cases of action which come apart from the applicability of our concept of action. But if this is the case then surely it is not our concept of action according to which the agent at issue can be said to act: what else, other than our application conditions associated with the concept, could fix the truth-conditions for ' $a$ acts'? Appeal to baptisms by ostension and other devices familiar from the literature on natural kind expressions is not going to help in this case.

\section{Tu quoque!}

Up until this point I have argued that pantheism is incompatible with the claim that God is a person, that (1) and (2) above form an inconsistent set. It would be understandable, but hasty, to conclude on this basis that if we want to maintain both that God exists and that God is a person then we ought to embrace theism of the kind standardly discussed in analytic philosophy of religion (Swiburnian theism). This, I will now argue, is a mistake since the reasons pantheism is incompatible with divine personhood are also reasons Swinburnian theism is incompatible with divine personhood.

Recall the earlier quoted passage from Swinburne in which God is described as:

a person without a body (i.e. a spirit), present everywhere, the creator and sustainer of the universe, a free agent, able to do everything (i.e. omnipotent), knowing all things, perfectly good, a source of moral obligation, immutable, eternal, a necessary being, holy, and worthy of worship. (Swinburne 2016, 2)

Call the conjunction of claims about God made here, minus the one that God is a person, Swinburnian theism. Swinburnian theism allows neither that God is a 
language user nor that God has a life context. If these are reasons to reject the compatibility of pantheism with divine personhood, then, they are also reasons to reject the compatibility of Swinburnian theism with divine personhood.

First consider membership of a linguistic community (remember that we are taking this as a prerequisite for content possession). Here the Swinburnian theist might seem to be in a better position than the pantheist. For is it not usual for theists to talk of God speaking to non-divine agents, who in turn speak to God in prayer? ${ }^{25}$ It is; however this will not secure membership of a linguistic community of the kind required for divine personhood. First, divine speech to the non-divine and nondivine speech to the divine are contingent realities. In particular, they depend on there being a non-divine reality. But God's act of creation is supposed to have been unforced (God is, after all, a 'free agent'). So God might not have been a member of a linguistic community. But then God is only contingently a person. This is not a result likely to be welcomed by the Swinburnian theist, for whom personhood belongs to the essence of God. ${ }^{26}$

Yet not even contingent membership of a linguistic community looks safe for the Swinburnian God. That God is supposed to be disembodied and immutable. The capacity to use language on the other hand is an acquired bodily aptitude (we considered above the case of an agent who had never not possessed a language). God, by Swinburnian definition, does not have a body and cannot—as immutableacquire any aptitudes. It might be replied that, whilst God does not have a body, the entirety of creation constitutes a domain through which God can speak, bringing about events analogous with the moving of hands to write or lips to speak. If this route is taken, though, the Swinburnian theist finds herself in the same situation as the pantheist: there is nothing external to the 'body' which is deployed in speaking. We have seen already, in the case of pantheism, that this situation is incompatible with membership of a linguistic community.

Nor does Swinburnian theism allow that there is a stage on which God's life is played out in the fashion required for personhood. God is 'present everywhere' and omnipotent. There is, then, nothing that lies beyond God's remit and nothing which could not be God's action. ${ }^{27}$ Just as in the case of pantheism there is nothing that could

\footnotetext{
25 On divine speaking see, for instance, Wolterstorff (1995). But, for a striking denial from a biblical critic, motivated by a thomistic understanding of God see Brown (1981). This is noteworthy in that it calls into question the move from lived religion and its language of divine speech and revelation to metaphysical claims about divine personhood.

${ }^{26}$ A referee asks whether Swinburne's social trinitarianism might be of help (Swinburne 1994). Certainly it seems that the suggestion that there are three divine individuals might provide a way to suggest that each divine individual could be part of a linguistic community; similarly the shared life of the Trinity could furnish each divine person with a life context. I have profound doubts that once the details are filled in, social trinitarianism will be of help. Whether or not that is right, it is hardly a victory for the proponent of divine personhood that there could be (three) divine persons if Swinburnian social trinitarianism is correct. Even amongst Christian philosophers of religion Swinburne's trinitarian theology has been the object of much criticism (Tuggy 2004; Clark 1996). I myself view it as a form of tritheism and so inconsistent with the Christian creeds of which it is supposed to provide an elucidation.

27 Swinburne himself would make an exception for the libertarian free actions of human agents. This does not look like it will secure enough for God to have a stage on which to act. For, at any time, any observed event could be a case of divine action.
} 
constitute an event as an action of God's, in the univocal sense of 'action' whereby actions are performed by persons. ${ }^{28}$ Nor, for that matter, do the interactions described between the faithful and God in prayer have the form of an exchange between speakers of a shared language where each party can recognise a publicly accessible and comprehensible action of the other as an utterance in a language and respond accordingly to reasons put forward by her conversational interlocutor. God's speaking to the praying person is not public; watching somebody in the act of prayer is sufficient to understand this. Hearing the 'voice' of God is, for the believer, an often painful introspective process, which involves distinguishing thoughts, desires, and impulses taken to come 'from God' from ones taken to be of no religious significance. To make these observations is in no way to undervalue prayer, but rather to recognise that it cannot be categorised as a series of exchanges within a community such that God could be identified as a discrete agent with a distinct sphere of influence.

Swinburnian theism cannot deliver that God is a language user, nor that there is a stage on which God's life is played out. It cannot therefore allow that God is a person. Given that most Swinburnian theists wish to affirm divine personhood, they are in an inconsistent position. Consistency could, of course, be restored by abandoning divine personhood. We will now explore that avenue briefly by way of conclusion.

\section{Conclusion}

Pantheism is incompatible with the claim that God is a person. The greater part of this paper has worked through arguments to that familiar conclusion. However, as we have seen, those arguments also show that Swinburnian theism is incompatible with the claim that God is a person. Faced with these conclusions, the philosopher of religion has a number of options. She can try to find something wrong with the arguments, to show that they do not in fact show that pantheism is incompatible with divine personhood, or that Swinburnian theism is incompatible with divine personhood, or either. Alternatively she might become an atheist.

Perhaps more interestingly, however, the philosopher of religion might revise her conception of God in order to restore coherence. One way in which this task could be undertaken would involve modifying the conception so as to be compatible with divine personhood. I conjecture that this will prove difficult if not impossible. The reason that both pantheism and Swinburnian theism fell victim to the arguments assayed above is that both deny that God is an item in the world comparable to ourselves (for the pantheist, God is the world; for the Swinburnian, God transcends the world). It is very difficult to imagine a conception of God which is genuinely a conception of God for which this is not the case. Better, then, to revisit the claim that God is a person. ${ }^{29}$ Whilst approached within much recent philosophy as though it were something like an analytic

\footnotetext{
${ }^{28}$ I myself don't want to deny that there is a sense of the word 'action' under which it is true to say that God performs actions. It is, however, not one which licenses the move from action to personhood. Extended discussion is a matter for another paper.

29 For an earlier case to the same effect see Thatcher (1985).
} 
truth, this has been questioned by a fringe of scholars, and as Brian Davies has pointed out it is of recent vintage within the history of religion (Davies 2016, 64-65). That God is a person is a dogma, in the Quinean rather than the ecclesiastical sense. An engagement with pantheism could wake the philosophy of religion from its slumbers.

Acknowledgements Thanks to Gail Leckie, Jonathan Nassim, Tasia Scrutton, and Mark Wynn for useful discussions. In particular, thanks are due to the Pantheism and Panentheism project at the University of Birmingham for financial support for the research which led to this paper, and to the Templeton Foundation for funding that project.

Open Access This article is distributed under the terms of the Creative Commons Attribution 4.0 International License (http://creativecommons.org/licenses/by/4.0/), which permits unrestricted use, distribution, and reproduction in any medium, provided you give appropriate credit to the original author(s) and the source, provide a link to the Creative Commons license, and indicate if changes were made.

\section{References}

Anscombe, G. E. M. (1957). Intention. Cambridge, MA: Harvard University Press.

Anscombe, G. E. M. (1958). Modern moral philosophy. Philosophy, 33(124). http://www.philosophy .uncc.edu/mleldrid/cmt/mmp.html. Accessed 5 July 2018.

Armstrong, D. M. (1997). A world of states of affairs. Cambridge: Cambridge University Press.

Brandom, R. B. (1994). Making it explicit : reasoning, representing, and discursive commitment. Cambridge, MA: Harvard University Press.

Brown, R. (1981). The critical meaning of the Bible. New York: Paulist Press.

Buckareff, A., \& Nagasawa, Y. (Eds.). (2016). Alternative concepts of god: Essays on the metaphysics of the divine. Oxford: Oxford University Press.

Clark, K. (1996). Trinity or tritheism? Religious studies, 32(4), 463-476.

Davies, B. (2016). Thomas Aquinas's Summa contra gentiles-a guide and commentary. Oxford: Oxford University Press.

Kripke, S. (1981). Naming and necessity. Oxford: Blackwell.

Mackie, J. L. (1982). The miracle of theism. Oxford: Oxford University Press.

Mander, W. (2016). Pantheism. In E. Zalta (Ed.), Stanford Encyclopedia of Philosophy.

Nagasawa, Y. (2017). Maximal God: A new defence of perfect being theism. Oxford: Oxford University Press.

Novaes, C. D. (2016). Reductio ad absurdum from a dialogical perspective. Philosophical Studies, 173(10), 2605-2628.

Nussbaum, M. C. (2001). Upheavals of thought: The intelligence of emotions. Cambridge: Cambridge University Press.

Oppy, G. (1997). Pantheism, quantification, and mereology. The Monist, 80(2), 320-336.

Plantinga, A. (1980). Does God have a nature? Milwaukee: Marquette University Press.

Steward, H. (2012). A metaphysics for freedom. Oxford: Oxford University Press.

Swinburne, R. (1994). The Christian God. Oxford: Oxford University Press.

Swinburne, R. (2016). The coherence of theism (2nd ed.). Oxford: Oxford University Press.

Tempest, K. (2013). Brand new ancients. London: Palgrave Macmillan.

Thatcher, A. (1985). The personal god and the God who is a person. Religious Studies, 21(1), 61-73.

Thornton, T. (1998). Wittgenstein on language and thought: The philosophy of content. Edinburgh: Edinburgh University Press.

Tuggy, D. (2004). Divine deception identity and social trinitarianism. Religious Studies, 40, 269-287.

Turner, D. (2002). How to be an atheist. New Blackfriars, 83(977-978), 317-335.

Uzquiano, G. (2004). The supreme court and the supreme court justices: A metaphysical puzzle. Nous, $38(1), 135-153$.

Wolterstorff, N. (1995). Divine discourse: Philosophical reflections on the claim that God speaks. Cambridge: Cambridge University Press. 